$\xi=-1$

\title{
Review of Corporate Governance Practices and Financial Distress Prediction
}

\author{
Syed Muhammad Ahmad Hassan Gillani ${ }^{1 *}$, Suresh Ramakrishnan², Hamad Raza ${ }^{3}$, Humara Ahmad $^{4}$ \\ ${ }^{1,2,3,4}$ Azman Hashim International Business School, Universiti Teknologi Malaysia (UTM), 81310 Johor Bahru, Johor, Malaysia. \\ *Corresponding author E-mail: ahmadgillani@gcuf.edu.pk
}

\begin{abstract}
Good corporate governance practices play an import role in increasing the firm value. Based on the agency theory related to corporate governance, if an agent (management) does not protect interest of principal (shareholders) then, agency cost is occurred and this creates a bad impact on the corporate performance. Therefore, it is necessary to address weak corporate governance practices in early stages otherwise firms can go in financial distress and eventually become bankrupt. The objective of this current study is to conduct a nonsystematic review of literature on theories and models related to corporate governance and financial distress. In the light of thorough review of literature, it is found that corporate governance variables (i.e. ownership concentration, board size, board composition, CEO duality, level of independence of board from management and managerial ownership) are good predictors for predicting financial distress. Moreover, it is also found that these corporate governance variables were not only used separately for predicting financial distress but also used along with others variables (firm level and country level) for the purpose of enhancing quality of financial distress models.
\end{abstract}

Keywords: Corporate Governance, Nonsystematic Review, Financial Distress, Agency Theory.

\section{Introduction}

The issue of corporate financial distress has always been point of focus for researchers. When companies do not take necessary actions at initial stage of financial distress then it may leads towards bankruptcy. For this reason, both financial distress and bankruptcy studies are used interchangeability. Financial distress including bankruptcy, suspension of securities and delisting which cause serious financial and social problems. Financial distress prediction is always challenging for researchers. In this regards extensive literature is available on distress prediction. Early studies are carried out by Beaver (1-2). Later on, many researchers continued research and incorporated new variables and applied new statistical tools for getting a better predictive ability (3-10). Chronology of some key research is mentioned in figure 1.1

Corporate governance includes mechanism, process and relationship by which corporations are controlled and directed. According to Butt (11), trust between lenders and investors is built on the principals of corporate governance. In the light of agency theory, corporate governance is linked with existence of agency problem and its roots can be traced back to separation of ownership and control of firm. In early studies of prediction financial distress, researchers used only accounting and economic variables as predictors. However in Chaganti et al. (12) used first time nonfinancial variable like corporate governance. Since 1980s, there is a large body of literature available that point out the importance of corporate governance and financial distress (12-19).

\section{Theories in Perspective of Financial Dis- tress and Corporate Governance}

Many empirical studies were carried out for default prediction, but could not successful to determine any established theory related to financial distress. However, financial distress and its implication faced the fundamental question of defining distress. In this regard as pioneers $(1-2,4)$ developed their own accounting based models to predict financial distress. Another school of thought is based on market information. Merton (20) developed a predictive model based on market data. Different models have their different aspects for measure and predict financial distress. They share the fact that bad financial performance and high leverage may increase financial distress. This study includes different theories in perspective of financial distress, some of them are available in finance literature which is discussed in specific and some theories of corporate governance and business sustainability are discussed in general.

\subsection{Static Trade- off Theory}

In order to understand financial distress, one should understand the capital structure choices. To determine the optimal capital structure, it has always been challenging for researchers. In this regard, this issue has been widely discussed in finance literature since Modigliani (21). According to the static trade-off theory, interest is tax deductible so firms can increase debt in their capital structure for getting tax shield benefits. As the firms increase their debt utilization the value of firms is increased due to tax shield benefits. This debt utilization is suitable up to certain level but beyond certain level of debt, firms can face financial distress. 
Trade-off theory suggests that firm should tradeoff between tax benefits and cost of financial distress. Many business people agree that moderate borrowing saves taxes and excess leverage can lead into financial distress. However, some empirical evidence weak the theory e.g. Kester (22) found that return on assets is most significant variable for setting debt ratio. Moreover, researcher argues that if the firm earns higher profit, then no matter how much firm is taking debts.

\subsection{Signaling Theory}

Financial distress and probability of default is an important aspect of signaling theory. According to this theory, when firm adopts aggressive borrowing strategy then positive signal prevails in market. Investors perceive that firm's management is confident that can generate sufficient cash flows to meet current and futures obligations. Signaling theory was proposed by Ross (23). this theory is based on asymmetric information between management and investors. Theory is true only when management invests funds efficiently, but adverse situation may leads to financial distress and its related bankruptcy costs. Moreover, when firm faces financial distress then conflict may rise between shareholders and creditors. Normally when firms are in good health then creditors do not show serious concerns with management decision. However, firms take excessive borrowing only when there is lower level of bankruptcy costs.

\subsection{Agency Theory}

Agency theory is a supposition that explain the relationship between principal and agent and also explains that how to best organize relationship through which shareholders (principal) evaluates the work of management (agent).The theory argues that under the condition of asymmetric information, agency problem is raised. Moral hazard is an example of such problem. Moral hazard can occur when management (agent) has more information than principal (shareholders). Theory of firm was proposed by Jensen (24) this theory based upon conflict of interest between different parties e.g. shareholders, managers and creditors. Agency problems may arise in result of separation of capital providers (shareholders and lenders) and company management. The fundamental objective of agency theory is to minimize the agency problem and cost associated with it. Due to asymmetric information managers are well informed about company's growth so they can increase debt in capital structure (25).Agency theory and corporate governance both are designed to address the problems and costs resulting from agency conflict. Scope of agency problem and mechanism of corporate governance is different from one firm, industry or culture to another.

\subsection{Stewardship Theory}

Stewardship theory is based on socialology, psychology and views management as considering the long-term interest of a variety of stakeholders rather than its own self-interested short-term opportunistic behavior. Stewardship is defined by Hernandez (26) "the extent to which an individual (management) willingly subjugates his or her personal interest to act in protection of other's (stakeholders) long term welfare". This theory is very relevant to the emerging corporate sustainability. For the purpose of protecting interest of all stakeholders, this theory requires management to exercise due diligence and stands accountable for improving financial and non-financial indicators but management is not guided that how these indicators can be improved. As far as financial indicators of firm are concerns, this study includes financial sustainability as financial indicator and corporate governance as nonfinancial indicators.

\subsection{Stakeholder Theory}

Stakeholders of firm can be classified into two categories internal stakeholders(shareholders, Managers and employees) and external stakeholders (suppliers, lenders, creditors, customers, government agencies and society). Hannan (27) proposed stakeholder theory. According to this theory, form view of shareholders firm should work for profit maximization only but shareholders are not only stakeholder, interest of others stakeholders should be addressed and protected. Stakeholder theory is a theory of management and business ethics.

Financial sustainability is a common aspect of both shareholder theory and stakeholder theory. In context of shareholder wealth maximization, non-financial sustainability activities (environmental, social and governance) can create conflict. So In this regard stakeholder theory proposes that firm should also invest in environmental and social activities (28).

\section{Models for Predicting Financial Distress}

According to Aziz (29), there are three main types of default prediction studies based on employed models. These are: (a) the statistical models (b) the theoretical models and (c) the artificial intelligence models. These models are comparable with each other in term of their predictive quality. Statistical models are univariate or multivariate in nature and they focus on symptom of default, while information is normally taken from business accounts. Theoretical models are different from statistical models because they focus of qualitative side of default reasoning more over these models are multivariate and apply a statistical technique in order to provide qualitative support to the theoretical support. Finally, artificial intelligence models are based on computer technology and machine learning. These models are usually multivariate in nature and use information from business accounts.

\subsection{The Statistical Models}

Statistical models were used in earliest studies of default prediction. Initially studies were carried out by using univariate analysis. Later on researchers used multivariate techniques for improving prediction accuracy. FitzPatrick (30) was first researcher who used traditional financial ratio on paired sample of default and nondefault firms. Later on Beaver (1) did comprehensive study of discriminatory power of financial ratio, which helps for detection of default and non-default firms. The main characteristics of this univariate and it addresses only individual signal of firms' forthcoming bankruptcy.so classification can take place for only one ratio at a time

Univariate model is simple to use as involves single financial ratio as a single predictor of failure. at the same time this feature becomes its back draw because this model may give confusing and contradictive classification results for different financial ratios of same firm. For example classifying a company with poor profitability and above average liquidity would be very confusing (31) .To understand financial status of a firm is not an easy task and it cannot be explain by using single financial ratio, so it is necessary to incorporate other financial ratios for understanding the financial situation in best manners (32).

In order to solve the problem, Altman used multiple discriminant analysis (MDA). This statistical technique is usually used to classify an observation into many groups based their individual characteristics. Main advantage of MDA technique is dealing with classification problems is simultaneously analyzing its whole variable profile (2). Sample of 66 manufacturing firm divided equally into bankrupt and non-bankrupt groups, both groups data was collected from 1946 to 1965 . The average asset size of these firms was USD 6.4 million. After finalized sample 22 potential financial ratios were evaluated, these ratios were categorized into five different types named profitability, liquidity, solvency, leverage and 
activity. The final multiple discriminant as used to predict bankruptcy by Altum (2).

$Z=0.12 \cdot X 1+0.14 \cdot X 2+0.033 \cdot X 3+0.006 \cdot X 4+0.999 \cdot X 5$

Where

$X_{1}=$ working capital / total assets ratio, $X_{2}=$ retained earnings / total assets ratio, $X_{3}=$ earnings before interest and taxes / tota assets ratio, $X_{4}=$ market value of equity / book value of total debt ratio, $X_{5}=$ sale $/$ total asset ratio and $Z=$ index (Z score)

Altman's Z score model provided bankruptcy prediction before two years of occurrence of bankruptcy or financial failure. There were three types of zone discussed in Altman's study first if Z score greater than 2.99 then it is treated as safe zone or nonbankruptcy zone. If $\mathrm{Z}$ score between 1.81 and 2.99 is the zone of ignorance and lastly if $\mathrm{Z}$ score below 1.18 then is treated as danger or bankruptcy zone. Although discriminant analysis is widely used, but there are some disadvantages associated with its assumptions. Multivariate discriminant analysis (MDA) requires three assumptions. First independent variables in this model must be multivariate and normally distributed. Its classification is sensitive to the date when distribution of data is not normally distributed (33) but practically this assumption is normally ignored which may cause a major bias (34-36). Second assumption is about variance-covariance matrices, these matrices should be equal in failing and non-failing groups. Last assumption is that the prior probability default and the mis-classification of failed and non-failed firms.Logit analysis is another statistical technique that is used by many researchers to predict default and bankruptcy. Ohlson (4) introduced logit technique using firm-specific indicators. He noted that analytical power of any model depends on availability of information (financial ratio).

Ohlson used sample of 2058 non-bankrupt and 105 bankrupts firm and data was collected from 1970 to 1976 . He incorporated nine independent variables in his model are $\mathrm{X}_{1}=\log$ of total assets (SIZE), $\mathrm{X}_{2}=$ total liabilities $/$ total assets (TLTA), $\mathrm{X}_{3}=$ working capital / total assets (WCTA), $X_{4}=$ current liabilities / current assets (CLCA), $\mathrm{X}_{5}=1$ if total liabilities $>$ total assets, 0 otherwise (OENEG), $\mathrm{X}_{6}=$ net income $/$ total assets (NITA), $\mathrm{X}_{7}=$ funds provided by operations divided by total liabilities (FUTL), $\mathrm{X}_{8}=1$ if net income was negative for last two years. Ohlson model could prediction of bankruptcy before one and two years before event its accuracy is $96.1 \%$ and $95.5 \%$ respectively. According to Javid and Iqbal (37), Yu and Zhou, 2008) logit regression model is better than artificial neural network (ANN) in term of predictive ability.

\subsection{Theoretical Models}

Balance sheet decomposition measure and cash management theory are commonly used as theoretical models for default prediction. Firms generally attempt to maintain their balanced capital structure, in this regards balance sheet decomposition measures variation in balance sheet structure. Moreover these models address the change in capital structure but not considering the direction of change therefore these models should focus on the reason behind this change that change in capital structure is either due to company growth or company default. Consistent with this limitation, Moyer (38) argued that such decomposition measures are not appropriate predictors for financial distress.Cash flow theory states that major concern of all firms is to manage cash on short term basis. Although cash management theories explain well the reasons of default prediction but other than these measures, there are many other factors that might be good predictors for financial distress (29). In addition, theoretical models had been used in less number as compare to statistical and artificial intelligence models (39-40)

\subsection{Artificial Intelligence Models}

Artificial intelligence models are based on computer knowledge and machine technology. These models include different tech- niques such as recursive partitioning (6), neural network (41) rough sets (7) and support vector machines (42). These techniques were applied on cross sectional-data.

Recursive partitioning (RP) technique is also known as decision tree (DT). Frydman et al. (6) first time used this techniques for predicting financial distress topic. Later on many researchers applied this technique e.g. (43-46). It is very famous technique for classification and prediction.as compare to some statistical and data mining techniques, the main attraction of DT is that it represents rules of classification in such a form that human can easily understand even these rules can be easily applied on date in raw form (47-48)

Artificial Intelligence Networks (ANN) is another type of artificial intelligence technique which is computer program that imitate human brain function and learning process (49).first time this technique was applied in early 1990 for corporate default prediction then application of this technique got fame and currently some commercial loan are based on neural network models. Key advantage of neural network (NN) models is their flexibility to the data characteristics. These models can also deal with non-linear functions and complex pattern, moreover these models require no assumptions like MDA and they have ability to deal with missing or incomplete data (50).In machine learning, support vector machines (SVM) are supervised learning models with associated learning algorithms that analyze data for classifying distressed companies vs. solvent companies. In recent years some studies applied the support vector machine (SVM) to predict financial distress (51-52)

\section{Conclusion}

Early studies of financial distress were focusing only on financial and accounting information, as (1-2, 4) used only financial ratios. However, several researchers argue that financial data alone do not provide better predictive quality of financial distress. Therefore it is necessary to add variables related to corporate governance for building better models $(8,15,53)$.Corporate governance is a growing area of management studies, especially for developing economies. Corporate governance practices/ mechanism has been become a focus point for researchers. There are many variables can be used for measuring corporate governance in any organization. Corporate governance consists of two major aspects 1) Ownership Structure; and 2) Board Structure. On the basis of literature most important measures of corporate governance are ownership concentration, institutional ownership, managerial ownership board size, No. of independent directors and $\mathrm{CEO} /$ Chairman duality.

\section{References}

[1] Beaver, W. H. (1966). Financial ratios as predictors of failure. Journal of accounting research, 71-111.

[2] Altman, E. I. (1968). Financial ratios, discriminant analysis and the prediction of corporate bankruptcy. The journal of finance. 23(4), pp. 589-609.

[3] Norton, C. L. and Smith, R. E. (1979). A comparison of general price level and historical cost financial statements in the prediction of bankruptcy. Accounting Review. pp. 72-87.

[4] Ohlson, J. A. (1980). Financial ratios and the probabilistic prediction of bankruptcy. Journal of accounting research. pp. 109-131.

[5] Mensah, Y. M. (1984). An examination of the stationarity of multivariate bankruptcy prediction models: A methodological study. Journal of Accounting Research. pp. 380-395.

[6] Frydman, H., Altman, E. I. and KAO, D. L. (1985). Introducing recursive partitioning for financial classification: the case of financial distress. The Journal of Finance. 40(1), pp. 269-291.

[7] Dimitras, A., Slowinski, R., Susmaga, R. and Zopounidis, C. (1999). Business failure prediction using rough sets. European Journal of Operational Research. 114(2), pp. 263-280.

[8] Chen, H.-H. (2008). The timescale effects of corporate governance measure on predicting financial distress. Review of Pacific Basin Financial Markets and Policies. 11(01), pp. 35-46. 
[9] Ooghe, H. and Balcaen, S. (2015). Are failure prediction models widely usable? An empirical study using a Belgian dataset.

[10] Ramakrishnan, S., Nabi, A. A. and Anuar, M. A. (2016). Default Prediction in Pakistan using Financial Ratios and Sector Level Variables. International journal of economics and Financial Issues. 6(3S).

[11] Butt, S. A. and Hasan, A. (2009). Impact of ownership structure and corporate governance on capital structure of Pakistani listed companies.

[12] Chaganti, R. S., Mahajan, V. and Sharma, S. (1985). Corporate board size, composition and corporate failures in retailing industry [1]. Journal of Management Studies. 22(4), pp. 400-417.

[13] Daily, C. M. and Dalton, D. R. (1994). Bankruptcy and corporate governance: The impact of board composition and structure. Academy of Management journal. 37(6), pp. 1603-1617.

[14] Elloumi, F. and Gueyie, J.-P. (2001). Financial distress and corporate governance: an empirical analysis. Corporate Governance: The international journal of business in society. 1(1), pp. 15-23.

[15] Lee, T. S. and Yeh, Y. H. (2004). Corporate governance and financial distress: Evidence from Taiwan. Corporate governance: An international review. 12(3), pp. 378-388.

[16] Wang, Z.-J. and Deng, X.-L. (2006). Corporate governance and financial distress: Evidence from Chinese listed companies. Chinese Economy. 39(5), pp. 5-27.

[17] Sami, A., Jusoh, A., \& Qureshi, M. I. (2016). Does Ethical Leadership Create Public Value? Empirical Evidences from Banking Sector of Pakistan. International Review of Management and Marketing, 6(4S).

[18] Polsiri, P. and Sookhanaphibarn, K. (2009). Corporate distress prediction models using governance and financial variables: evidence from Thai listed firms during the East Asian economic crisis. Journal of Economics and Management. 5(2), pp. 273-304.

[19] Ciampi, F. and Gordini, N. (2013). The Potential of Corporate Governance Variables for Small Enterprise Default Prediction Modeling. Statistical Evidence from Italian Manufacturing Firms. Preliminary Findings. Proceedings of the 2013 Cambridge business and economics conference proceedings. pp. 1-19.

[20] Manzaneque, M., Priego, A. M. and Merino, E. (2016). Corporate governance effect on financial distress likelihood: Evidence from Spain. Revista de Contabilidad. 19(1), pp. 111-121.

[21] Merton, R. C. (1974). On the pricing of corporate debt: The risk structure of interest rates. The Journal of finance, 29(2), 449-470.

[22] Modigliani, F. and Miller, M. H. (1958). The cost of capital, corporation finance and the theory of investment. The American economic review. 48(3), pp. 261-297.

[23] Kester, W. C. (1986). Capital and ownership structure: A comparison of United States and Japanese manufacturing corporations. Financial management. pp. 5-16.

[24] Ross, S. A. (1977). The determination of financial structure: the incentive-signalling approach. The bell journal of economics. pp. 23-40.

[25] Jensen, M. C. and Meckling, W. H. (1976). Theory of the firm: Managerial behavior, agency costs and ownership structure. Journal of financial economics. 3(4), pp. 305-360.

[26] Jensen, M. C. (1986). Agency costs of free cash flow, corporate finance, and takeovers. The American economic review. 76(2), pp. 323-329.

[27] Hernandez, M. (2012). Toward an understanding of the psychology of stewardship. Academy of Management Review. 37(2), pp. 172193.

[28] Hannan, M. T. and Freeman, J. (1984). Structural inertia and organizational change. American sociological review. pp. 149-164.

[29] Clarkson, P. M., Li, Y., Richardson, G. D. and Vasvari, F. P. (2011). Does it really pay to be green? Determinants and consequences of proactive environmental strategies. Journal of Accounting and Public Policy. 30(2), pp. 122-144.

[30] Aziz, M. A. and Dar, H. A. (2004). Predicting Corporate Bankruptcy: whither do we stand?

[31] FitzPatrick, P. J. (1932). A comparison of the ratios of successful industrial enterprises with those of failed companies.

[32] Cascio, W. F., Young, C. E. and Morris, J. R. (1997). Financial consequences of employment-change decisions in major US corporations. Academy of management Journal. 40(5), pp. 1175-1189.

[33] Edmister, R. O. (1972). An empirical test of financial ratio analysis for small business failure prediction. Journal of Financial and Quantitative analysis. 7(2), pp. 1477-1493.

[34] Richardson, F. M. and Davidson, L. F. (1984). On linear discrimination with accounting ratios. Journal of Business Finance \& Accounting. 11(4), pp. 511-525.

[35] Eisenbeis, R. A. and Avery, R. B. (1972). Discriminant analysis and classification procedures: theory and applications.

[36] Deakin, E. B. (1976). Distributions of financial accounting ratios: some empirical evidence. The Accounting Review. 51(1), pp. 90-96.

[37] Mcleay, S. and Omar, A. (2000). The sensitivity of prediction models to the non-normality of bounded and unbounded financial ratios. The British Accounting Review. 32(2), pp. 213-230.

[38] Javid, A. Y., \& Iqbal, R. (2008). Ownership concentration, corporate governance and firm performance: Evidence from Pakistan. The Pakistan Development Review, 643-659.

[39] Moyer, R. C. (1977). Forecasting financial failure: a reexamination. Financial Management (pre-1986), 6(1), 11.

[40] Booth, P. J. (1983). Decomposition measures and the prediction of financial failure. Journal of Business Finance \& Accounting. 10(1), pp. 67-82.

[41] Laitinen, E. K. and Laitinen, T. (1998). Cash management behavior and failure prediction. Journal of Business Finance \& Accounting. 25(7- 8), pp. 893-919.

[42] Tam, K. Y. and Kiang, M. Y. (1992). Managerial applications of neural networks: the case of bank failure predictions. Management science. 38(7), pp. 926-947.

[43] Martens, D., Baesens, B., Van Gestel, T. and Vanthienen, J. (2007). Comprehensible credit scoring models using rule extraction from support vector machines. European journal of operational research. 183(3), pp. 1466-1476.

[44] Carter, C. and Catlett, J. (1987). Assessing credit card applications using machine learning. IEEE expert. 2(3), pp. 71-79.

[45] Messier Jr, W. F. and Hansen, J. V. (1988). Inducing rules for expert system development: an example using default and bankruptcy data. Management Science. 34(12), pp. 1403-1415.

[46] Pompe, P. and Feelders, A. (1997). Using machine learning, neural networks, and statistics to predict corporate bankruptcy. Computer-Aided Civil and Infrastructure Engineering. 12(4), pp. 267-276.

[47] Gepp, A., Kumar, K. and Bhattacharya, S. (2010). Business failure prediction using decision trees. Journal of forecasting. 29(6), pp. 536-555.

[48] Breiman, L., Friedman, J., Olshen, R. and Stone, C. (1984). Classification and regression tree. Wadsworth International Group, Belmont, $C A$.

[49] Hand, D. J., Mannila, H. and Smyth, P. (2001). Principles of data mining. MIT press.

[50] Balcaen, S. and Ooghe, H. (2006). 35 years of studies on business failure: an overview of the classic statistical methodologies and their related problems. The British Accounting Review. 38(1), pp. 63-93.

[51] Shachmurove, Y. (2002). Applying artificial neural networks to business, economics and finance. University of Pennsylvania, Center for Analytic Research in Economics and the Social Sciences.

[52] Härdle, W., Moro, R. and Schäfer, D. (2005). Predicting bankruptcy with support vector machines. In Statistical Tools for Finance and Insurance. (pp. 225-248). Springer.

[53] Chen, S., Härdle, W. and Moro, R. (2011). Modeling default risk with support vector machines. Quantitative Finance. 11(1), pp. 135-154.

[54] Fich, E. M. and Slezak, S. L. (2008). Can corporate governance save distressed firms from bankruptcy? An empirical analysis. Review of Quantitative Finance and Accounting. 30(2), pp. 225-251. 